GLOBAL JOURNAL OF GEOLOGICAL SCIENCES VOL. 18, 2020: 89-95

COPYRIGHT@ BACHUDO SCIENCE CO. LTD PRINTED IN NIGERIA ISSN 1596-6798

89

www.globaljournalseries.com, Email: info@globaljournalseries.com

\title{
AN ASSESSMENT OF HEAVY METALS CONCENTRATION IN WATER AROUND QUARRIES AND BARITE MINE SITES IN PART OF CENTRAL CROSS RIVER STATE, SOUTHEASTERN NIGERIA.
}

\author{
OCHELEBE, I., KUDAMNYA, E. A. AND NKEBEM, G. E.
}

(Received 18 May 2020; Revision Accepted 3 September 2020)

\begin{abstract}
The assessment of the level of heavy metal concentrations in water sources around quarries and barite mine sites in central Cross River State, Southeastern Nigeria, was carried out to evaluate the degree of contamination due to mining and quarrying activity in the area. The investigation involved the collection of twelve water samples from ponds, streams, river and boreholes around the area. The water samples were passed through $0.45 \mu \mathrm{m}$ filter paper and preserved with a drop of $0.1 \mathrm{M} \mathrm{HNO}_{3}$ acid. The preserved samples were analyzed for their heavy metal $(\mathrm{Ba}, \mathrm{Cr}$, $\mathrm{Cu}, \mathrm{Fe}, \mathrm{Mn}, \mathrm{Pb}$ and $\mathrm{Zn}$ ) content, using inductively coupled plasma-mass spectrometry (ICP-MS). The results show that the average concentration of $\mathrm{Ba}, \mathrm{Cu}, \mathrm{MN}, \mathrm{Pb}$ and $\mathrm{Zn}$ were above $\mathrm{WHO}$ guideline value for drinking water quality, hence not suitable for drinking. The average concentration of the metals is in the order $\mathrm{Ba}>\mathrm{Mn}>\mathrm{Cu}>\mathrm{Fe}>\mathrm{Pb}>\mathrm{Zn}>\mathrm{Cr}$. Computed values of contamination index show that the samples from four locations were contaminated. Single factor pollution index computation indicates that the waters are not contaminated with $\mathrm{Cr}$, but slightly polluted with $\mathrm{Fe}$ and $\mathrm{Zn}$, moderately polluted with $\mathrm{Ba}$ and severely polluted with $\mathrm{Cu}, \mathrm{Mn}$ and $\mathrm{Pb}$. Further, Nemerow comprehensive pollution index indicates that samples from four locations were severely contaminated. The study revealed that the water sources around the barite mines had elevated level of heavy metal concentration compared to location around the quarries. It is recommended therefore, that the water be treated before use for drinking purpose.
\end{abstract}

KEYWORDS- heavy metals, contamination index, pollution index, barite mine, quarry.

\section{INTRODUCTION}

The central part of Cross River State in Nigeria is very rich in solid minerals, this has led to the proliferation of mining activity in the area by both organize and illegal miners. This surge is attributed to the Federal Government of Nigeria policy on the use of local raw materials. The occurrence and exploitation of these minerals is a potential threat to the water resources within the vicinity of the mines and adjoining area. Rock quarrying and barite mining generates huge quantity of rock and mine tailings. These mine wastes can increase the levels of heavy metals released into the environment. Oxidation and released metals from unprotected mine waste sites are sources of environmental contamination and risk (Adamu et al., 2014). In recent time's heavy metals in soil and water is becoming an issue of concern at all levels, since these resources constitute a crucial component of our environment (Ochelebe et al., 2017).
Mining and release of heavy metals into the environment is a threat to human health because of its toxicity when their levels in drinking water exceeds the maximum admissible values set by international organizations such as World Health Organization. Elevated concentration of elements as a result of contamination can be measured ina number of ways. Hitherto, previous studies have employed the use of indices such as contamination index $(\mathrm{Cl})$ and pollution index(PI) (Yang etal., 2013; Adamu et al., 2014; Zhang et al., 2018).

Inhabitants within and around the study area mostly depend on water from existing rivers, streams and ponds for domestic purpose. To say the least, few people have access to well-designed and constructed boreholes provided by private owners and Cross River Basin Development Authority, an Agency of Federal Ministry of Water resources through their intervention programs. But this is not enough, so majority still depends on the not too-safe surface water sources such as streams, ponds and river for domestic use. The

Ochelebe, I., Department of Geology, University of Calabar, Calabar-Nigeria.

Kudamnya, E. A., Department of Geology, University of Calabar, Calabar-Nigeria.

Nkebem, G. E., Department of Geology, University of Calabar, Calabar-Nigeria. 
Nigerian National Statistics Office reports that in 2001, $66.5 \%$ of Cross Riverians rely on water from ponds/streams for domestic purposes (FOS, 2003). The Multiple Indicator Cluster Survey report of 2011 shows that $49.3 \%$ of Cross Riverians used unimproved water sources for domestic purposes (NBS, 2013). Furthermore, findings of National Nutrition and Health Survey 2014 , shows that $37.8 \%$ of household in Cross River State have access to improved drinking water sources (NBS, 2014), indicating that $62.2 \%$ of the population are exposed to unsafe water sources.

Geological, mineralogical and structural aspects of the rocks and barite occurrence have been investigated by previous authors (Ekwueme\&Onyeagocha,1986; Ekweme, 1995; Adamu, 2000, 2011; Egeh, et al., 2004; Oden, 2012). Adamuet al. (2014), assessed the contamination and health risk associated with abandoned barite mines in Cross River State generally, using streams and pond water.The hydrochemical assessment of pond and stream waters and trace and major element pollution of the sediments around some of the barite mineshave been investigated (Adamuet al.,2013; Adamuet al., 2015). However, this study is on the environmental aspect, with emphasis on the effect of the quarry activities and barite mining on available water sources and the risk on human health. The objective is to appraise and update the level of heavy metal in both surface and groundwater sources within and around the quarries and mine sites and appraising the degree of contamination.

\section{DESCRIPTION OF STUDY AREA}

Six (6) communities namely;Obung, Ojor, Iwuru, Nkonemba, Ikot Okpora and Ibogo in Cross River State, Southeastern Nigeria, where mining is taking place were investigated. During sampling large scale quarrying of granite and granodiorite was going on in Obung, Ojor, Iwuru, Old Netim, Nkonemba and Ikot Okpora area, while barite mining on medium to small scale was going on in Ibogo area. Information from the community leaders revealed thatmodern quarrying activity in the area started around 1971 in Old Netim during the construction of the major highway in the area, and the latest is the Iwuru quarry that was established around 2012. While barite mining started around 2004 in Ibogo area.

The area lies within longitudes $8^{\circ} 00^{\prime}$ to $8^{\circ} 30^{\prime} \mathrm{E}$ and latitudes $5^{\circ} 20^{\prime} \mathrm{N}$ to $5^{\circ} 45^{\prime} \mathrm{N}$. It is accessed through a major road, the Calabar-lkom highwayandminor roads such as; Unyanga-Ifunkpa road, Ayaba-lkot Okpora road, Abini-Agwuagune roads, and various footpaths leading to sampling points. The area is drained majorly by Cross River and other smaller rivers and streams(Fig.1). Some of these streams are; Ikpaya, Ayiboniong, Eyuma, Ageden, Ekpendu-Iwuru, Efajene and Ugbam streams. Most of the streams flow in the NE-SW direction. The relief of the area is undulating, with some minor hills and valleys. The mean annual rain fall in the area was reported to be about $2,300 \mathrm{~mm}$ (CRBDA, 2008). With temperature ranging between $25^{\circ} \mathrm{C}$ and $35^{\circ} \mathrm{C}$ (lloeje, 1991).

\section{GEOLOGY}

The study area is underlain by two major rock formations, the Oban Massif to the south and the IkomMamfe Embayment to the north. The rocks of the southern part are mainly of igneous and metamorphic origin (granodiorites, phyllites, schists,gneisses, amphibolites, pegmatites, granites, tonalities, monazites, dolerites, and charnockites). The gneisses grade into schist which is intruded by granodiorite and pegmatitein some parts. A sharp contact exists between the schist and calcareous sandstone in the north-western partof the study area (Fig.1). Geochemical studies of the gneisses by Ekwueme and Onyeagocha (1986) shows that they are metasediments of shale-greywacke. The granodiorite is the most extensive intrusive in the study area. The rocks are coarse-grained, non-foliated and have a sharp contact with the schist. Geochemical studies of the schists at Ikot-Ana show them to consist typically ofmetasediments, which have a composition characteristic of phyllites and semi-phyllites. The rock sequence of the Mamfe Embayment consists of sandstones and mudstones(Ekwueme, 1995). 


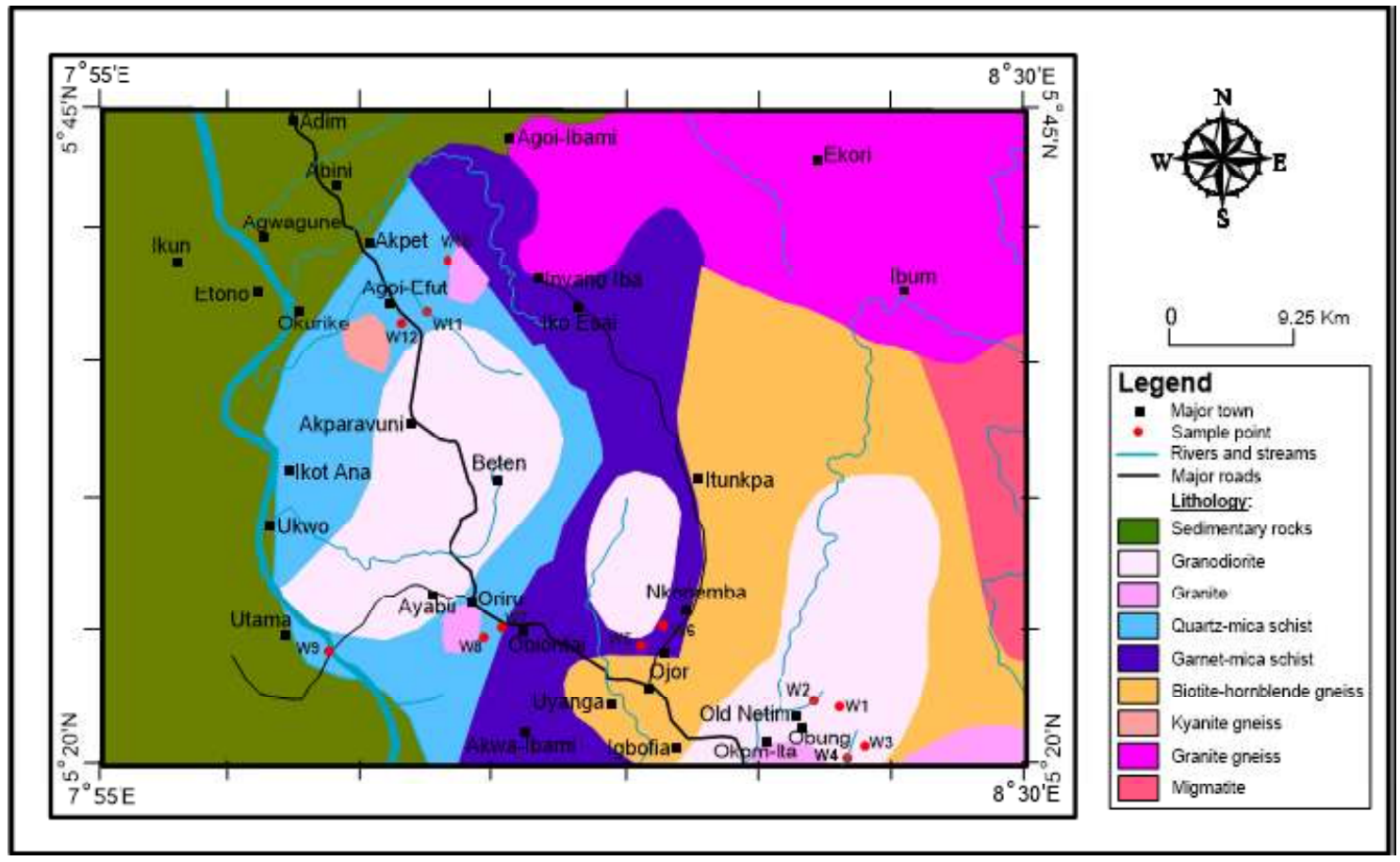

Fig. 1: Geologic Map of the Study Area with sample locations (Modified from Ekwuemeet al., 1995)

\section{METHODOLOGY}

A total of twelve (12) water samples consisting of four boreholes, four streams, three ponds and one river, were collected within and aroundlocations of thebarites minesand quarries sites (Fig. 1). Table 1 shows the locations and co-ordinates of the sampling points. Water samples were taken from mine ponds, streams and boreholes, and stored in 1 litre polythene bottles. Prior to the collection of water samples, the sample bottles were rinsed thoroughly with the water to be collected. During the collection of groundwater, the borehole was pumped for about 10 minutes to ensure stability, the water samples were then collected at the well head. The samples were pass through $0.45-\mu \mathrm{m}$ membrane filter paper.

The samples were preserved with a drop of $0.1 \mathrm{M} \mathrm{HNO}_{3}$, to prevent precipitation of the metals from the water. Thewater samples were then stored in a cooler at $4^{\circ} \mathrm{C}$ and taken to the laboratory for the analysis of their trace element contents using inductively coupled plasmamass spectrometry (ICP-MS) at Acme LaboratoryLimited, Vancouver Canada.

Contamination index was computed to identify the enrichment of heavy metals with respect to the maximum admissiblelimit (MAL) standards (WHO, 2008). The contamination indexes for

Table 1:Location and Co-ordinates of sampling points.

\begin{tabular}{|c|c|c|c|c|c|}
\hline \multirow[t]{2}{*}{ Loc. ID } & \multirow[t]{2}{*}{ Area } & \multirow[t]{2}{*}{ Quarry type } & \multirow{2}{*}{$\begin{array}{l}\text { Water } \\
\text { Type }\end{array}$} & \multicolumn{2}{|l|}{ Co-ordinate } \\
\hline & & & & Longitude & Latitude \\
\hline W1 & Old Netim & Granite & Pond & 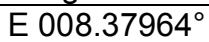 & $\mathrm{N} 05.36329^{\circ}$ \\
\hline W8 & Iwuru & Granodiorite & Pond & $\mathrm{E} \mathrm{008.15846}^{\circ}$ & $\mathrm{N} 05.42472^{\circ}$ \\
\hline W10 & Igbogo & Barite mine & Pond & E $008.14136^{\circ}$ & N 05.62878 \\
\hline W2 & Old Netim & Granite & Stream & E $008.37278^{\circ}$ & $\mathrm{N} 05.37422^{\circ}$ \\
\hline W4 & Obung & Granite & Stream & $E^{2008.38682^{\circ}}$ & $\mathrm{N} 05.34129^{\circ}$ \\
\hline W6 & Nkonemba & Granite & Stream & $\mathrm{E} \mathrm{008.28652}^{\circ}$ & $\mathrm{N} 05.43504^{\circ}$ \\
\hline W11 & Igbogo & Barite mine & Stream & E 008.12517 & $\mathrm{N} 05.60970^{\circ}$ \\
\hline W9 & $\begin{array}{l}\text { Ikot } \\
\text { Okpora }\end{array}$ & Granodiorite & River & $\mathrm{E} \mathrm{008.07167^{ \circ }}$ & $\mathrm{N} 05.40575^{\circ}$ \\
\hline W3 & Obung & Granite & Borehole & E $008.39580^{\circ}$ & $\mathrm{N} 05.34685^{\circ}$ \\
\hline W5 & Ojor & Granite & Borehole & E 008.27431 & N $05.40929^{\circ}$ \\
\hline W7 & Iwuru & Granodiorite & Borehole & E $008.17486^{\circ}$ & N $05.41894^{\circ}$ \\
\hline W12 & Igbogo & Barite mine & Borehole & E 008.12000 & $\mathrm{N} 05.60372^{\circ}$ \\
\hline
\end{tabular}

*W1-W9= water samples from quarry areas, $\mathrm{W} 10-\mathrm{W} 12=$ water samples from barite mine area. 
the potentiallytoxic elements (PTEs) in the water was calculated using Equation. (1). The contamination index is classified as presented in Table 2.

$C_{a}=\frac{1}{n} \sum_{i=1}^{n}\left(\frac{M_{a i}}{S_{a i}}\right) \ldots \ldots 1$

Where;

$C_{a}$ is the contamination index of sample a

$M_{a i}$ is the concentration of metal in sample a

$S_{a i}$ is the maximum admissible limit of metal $i$ base on standard

$n$ is the total number of metals considered

Inorder to determine the degreeof contribution of each metal to toxicity of the water in the area, the single factor index, Nemerow pollution index(Yang etal., 2013) was useful. The single-factor pollutionindex can weigh the pollution of single contamination and is applied to establish water quality parameters. The Nemerowcomprehensive pollution index is widely applied to reflect the total pollution level andevaluate environmental quality (Zhang et al., 2018). The Nemerow pollution index is calculated using the following equations;

$F_{i j}=\frac{c_{i j}}{s_{i j}} \ldots \ldots \ldots \ldots . . .2$

$P I=\sqrt{\frac{1}{2}\left(F_{\max }^{2}+F_{\text {ave }}^{2}\right)} \ldots \ldots \ldots . . .3$

Where;

$F_{i j}$ is the pollution index of the ith potentially toxic element in $j$

$\mathrm{C}_{\mathrm{ij}}$ is the concentration of the ith potentially toxic element in $\mathrm{j}$

$\mathrm{S}_{\mathrm{ij}}$ is the required standard of the ith potentially toxic element in $\mathrm{j}$

$\mathrm{PI}$ is the Nemerowcomprehensive pollution index

$F_{\text {max }}$ is the maximum Single factor pollution index of all the potentially toxic element

$F_{\text {ave }}$ is the average single factor pollution index of all the potentially toxic element

the Nemerow pollution index is categorized as presented in Table 2.

Table 2:Classes of Contamination and Nemerow Pollution Indices

\begin{tabular}{|l|l|l|l|}
\hline \multicolumn{2}{|l|}{ Contamination Index } & Nemerow Pollution Index \\
\hline Indices & Degree of contamination & Indices & Degree of contamination \\
\hline $\mathrm{Cl}<1$ & Not contaminated & $\mathrm{Pl} \leq 1$ & Not contaminated \\
\hline $1<\mathrm{Cl}<5$ & Slightly contaminated & $1<\mathrm{PI} \leq 2$ & Slightly contaminated \\
\hline $\mathrm{Cl}>5$ & Contaminated & $2<\mathrm{Pl} \leq 3$ & Moderately contaminated \\
\hline & & $\mathrm{PI}>3$ & Severely contaminated \\
\hline
\end{tabular}

\section{RESULTS AND DISCUSSION}

The result of the heavy metals concentration in the water samples collected and analyzedis presented in Table 3 . The result shows that the $\mathrm{pH}$ ranged between 5.800 (W11) and 7.200(W5 and W6), with amean value of 6.700. The concentration of Ba ranged between 0.010 $\mathrm{mg} / \mathrm{l}$ (W2) and $13.800 \mathrm{mg} / \mathrm{l}$ (W10) with mean concentration of $1.990 \mathrm{mg} / \mathrm{l}$. The concentration of $\mathrm{Cr}$ was below detection limit at locations W2, W3, W4 andW8,with the highest value of $0.030 \mathrm{mg} / \mathrm{l}$ (W12). The mean concentration of $\mathrm{Cr}$ computed was $0.005 \mathrm{mg} / \mathrm{l}$. Also, $\mathrm{Cu}$ was below detection limit at locations $\mathrm{W} 1, \mathrm{~W} 2$, W3, W7 and W8, while the highest value was $5.150 \mathrm{mg} / \mathrm{l}$ (W10), and amean concentration of $0.772 \mathrm{mg} / \mathrm{l}$. Fe was below detection at locations W3, W2, W5, W7 and W10 and the highest value of $4.100 \mathrm{mg} / \mathrm{l}(\mathrm{W} 10)$. The mean value computed was $0.586 \mathrm{mg} / \mathrm{l}$. The concentration of Mnwas below detection at locations W1, W4, W5, W6, W8 and W9, while highest value of $4.790 \mathrm{mg} / \mathrm{l}$ (W11) was recorded. The mean concentration of $1.110 \mathrm{mg} / \mathrm{l}$ was computed. Concentration values of Pbwas below detection limit at locations W1, W2, W3, W4, W5, W6, W7, W8 and W9, while the highest value of $1.130 \mathrm{mg} / \mathrm{l}$ (W11)was recorded. The meanconcentration value of $0.274 \mathrm{mg} / \mathrm{l}$ was obtained for $\mathrm{Pb}$. The concentration of $\mathrm{Zn}$ was below detection at locations $\mathrm{W} 1, \mathrm{~W} 5, \mathrm{~W} 8$ and $\mathrm{W} 9$, and the highest value of $0.270 \mathrm{mg} / \mathrm{l}$ (W10) was obtained. However, a mean concentration of $0.079 \mathrm{mg} / \mathrm{l}$ was computed for $\mathrm{Zn}$.

Generally, the mean concentration of the heavy metals in the area is in the order $\mathrm{Ba}>\mathrm{Mn}>\mathrm{Cu}>\mathrm{Fe}>\mathrm{Pb}>\mathrm{Zn}>\mathrm{Cr}$.Comparison of these data within the different watersourcesreveal that the concentration of all the metals, except $\mathrm{Cr}$ and $\mathrm{Zn}$, were higher in water sampled from the ponds. This conforms with the assertion byAdamuet al. (2014). Also, the concentration of all the heavy metals were higher in the samples collected around the barite mines as compared with those of the quarry sites. 
Table 3: Results of heavy metal concentrations in water samples from the study area.

\begin{tabular}{|c|c|c|c|c|c|c|c|c|c|}
\hline Loc.ID & Water Type & $\mathbf{P h}$ & $\begin{array}{l}\mathrm{Ba} \\
(\mathrm{mg} / \mathrm{l})\end{array}$ & $\begin{array}{l}\mathrm{Cr} \\
(\mathrm{mg} / \mathrm{l})\end{array}$ & $\begin{array}{l}\mathrm{Cu} \\
(\mathrm{mg} / \mathrm{l})\end{array}$ & $\begin{array}{l}\mathrm{Fe} \\
(\mathrm{mg} / \mathrm{l})\end{array}$ & $\begin{array}{l}\mathrm{Mn} \\
(\mathrm{mg} / \mathrm{l})\end{array}$ & $\begin{array}{l}\mathrm{Pb} \\
(\mathrm{mg} / \mathrm{l})\end{array}$ & $\begin{array}{l}\mathrm{Zn} \\
(\mathrm{mg} / \mathrm{l})\end{array}$ \\
\hline W1 & Pond quarry & 6.800 & 0.020 & 0.003 & ND & 0.018 & ND & ND & ND \\
\hline W8 & Pond quarry & 6.700 & 0.020 & ND & ND & 0.013 & ND & ND & ND \\
\hline W10 & Pond barite & 6.700 & 13.800 & 0.010 & 5.150 & 4.100 & 4.310 & 1.104 & 0.270 \\
\hline \multicolumn{2}{|l|}{ Mean } & 6.733 & 4.613 & 0.004 & 1.717 & 1.377 & 1.437 & 0.368 & 0.09 \\
\hline W2 & $\begin{array}{l}\text { Stream } \\
\text { quarry }\end{array}$ & 6.600 & 0.010 & ND & ND & ND & 0.014 & ND & 0.002 \\
\hline W4 & $\begin{array}{l}\text { Stream } \\
\text { quarry }\end{array}$ & 7.200 & 0.020 & ND & 0.001 & 0.021 & ND & ND & 0.002 \\
\hline W6 & $\begin{array}{l}\text { Stream } \\
\text { quarry }\end{array}$ & 6.800 & 0.020 & 0.001 & 0.001 & 0.039 & ND & ND & 0.009 \\
\hline W9 & River quarry & 7.000 & 0.020 & 0.001 & 0.001 & ND & ND & ND & ND \\
\hline W11 & $\begin{array}{l}\text { Stream } \\
\text { barite }\end{array}$ & 5.800 & 5.600 & 0.010 & 1.760 & 1.800 & 4.790 & 1.130 & 0.210 \\
\hline \multicolumn{2}{|l|}{ Mean } & 6.680 & 1.134 & 0.002 & 0.353 & 0.372 & 0.983 & 0.226 & 0.045 \\
\hline W3 & $\begin{array}{l}\text { Borehole } \\
\text { quarry }\end{array}$ & 7.000 & 0.030 & ND & ND & ND & 0.011 & ND & 0.003 \\
\hline W5 & $\begin{array}{l}\text { Borehole } \\
\text { quarry }\end{array}$ & 7.200 & 0.070 & 0.004 & 0.001 & ND & ND & ND & ND \\
\hline W7 & $\begin{array}{l}\text { Borehole } \\
\text { quarry }\end{array}$ & 6.700 & 0.200 & 0.002 & ND & ND & 0.021 & ND & 0.230 \\
\hline W12 & $\begin{array}{l}\text { Borehole } \\
\text { barite }\end{array}$ & 5.900 & 4.120 & 0.030 & 2.350 & 0.800 & 4.190 & 1.056 & 0.230 \\
\hline \multirow{2}{*}{\multicolumn{2}{|c|}{$\begin{array}{l}\text { Mean } \\
\text { Summary of result }\end{array}$}} & 6.700 & 1.105 & 0.009 & 0.588 & 0.200 & 1.056 & 0.264 & 0.116 \\
\hline & & & & & & & & & \\
\hline \multicolumn{2}{|c|}{$\begin{array}{l}\text { Average } \\
\text { Quarries }\end{array}$} & 6.89 & 0.046 & 0.001 & 0.001 & 0.010 & 0.005 & 0.000 & 0.027 \\
\hline \multicolumn{2}{|c|}{$\begin{array}{l}\text { Average around } \\
\text { barite mines }\end{array}$} & 6.167 & 11.173 & 0.017 & 3.087 & 2.233 & 4.430 & 1.067 & 0.237 \\
\hline \multicolumn{2}{|c|}{ Overall Mean } & 6.700 & 1.994 & 0.005 & 0.7720 & 0.566 & 1.111 & 0.274 & 0.079 \\
\hline \multicolumn{2}{|c|}{ Minimum } & 5.800 & 0.010 & 0 & 0 & 0 & 0 & 0 & 0 \\
\hline \multicolumn{2}{|c|}{ Maximum } & 7.200 & 13.800 & 0.030 & 5.150 & 4.100 & 4.790 & 1.130 & 0.270 \\
\hline \multicolumn{2}{|l|}{ WHO } & $\begin{array}{l}6.5- \\
8.0\end{array}$ & 0.7 & 0.050 & 0.050 & 0.300 & 0.300 & 0.010 & 0.050 \\
\hline
\end{tabular}

- ND - Not detected

\section{CONTAMINATION ASSESSMENT}

The meanconcentration levels of the various parameters analyzed,when compared with standard guidelines fordrinking water quality by WHO (2008), show that mean concentrations of $\mathrm{Ba}, \mathrm{Cu}, \mathrm{Mn}$ and $\mathrm{Pb}$ obtained in all the water sources werehigher (Table 3).It further reveals that concentration levels of $\mathrm{Cr}$ are higher in the boreholes, $\mathrm{Fe}$ is higher in streams, rivers and ponds. While Znis higher in ponds and boreholes water.

The resultsshow that the mean concentration of the metals around the quarry sites (W1 to W9) for all the water sources were found to lie within permissible limits for drinking water quality by WHO standard.This indicatesthat there is no noticeable effect of quarry activities on water quality at present.The locations around the barite mines (W10, W11 and W12), have concentration level higher than the permissible limits for drinking water quality. Water samples obtained and analyzed from the ponds had a higher concentration of heavy metals when compared to those from the boreholes and other surface water. This suggests that activities within and around the barite mines may have adversely affected water quality in the area. The consumption of water with concentration of these heavy metals above the permissible limit could lead to a wide range of health challenges such as gastrointestinal disorder, neurological disorder, defect in infant mental development and cancer (SON, 2015). Though no information on such health challenges were reported or documented in existing literatures as at the time of this study. However, communities within and around the study area may be at severe health risk by drinking from these water sources.

The contamination indices were computed and the contamination class for each location is presented in Table 4.Comparatively, values of $\mathrm{Cl}>5$ indicates high contamination, and these were obtained from locations W10, W11 and W12. These are related to anthropogenic activities and probably resulting from barite mining in the area. Location W7 which is outside the barite mines, had a $\mathrm{Cl}$ value of 5.0 which indicate contamination, this could be as a result of the high concentration of $\mathrm{Zn}$ which contributed to the high index value (Table 5). Therefore, about $33 \%$ of the water samples analyzed from the entire study area were contaminated. Other locations such as; W1, W2, W3, W4, W5, W6, W8 and W9, have low average values indicating that they are not polluted with respect to the heavy metals. 
Single factor pollution indices $(F)$ and the Nemerow comprehensive pollution Indices (PI) are summarized in Table 5. The average F-values computed were ranked in the order as follows; $\mathrm{Pb}>\mathrm{Cu}>\mathrm{Mn}>\mathrm{Ba}>\mathrm{Fe}>\mathrm{Zn}>\mathrm{Cr}$. It suggests that $\mathrm{Pb}, \mathrm{Cu}$ and $\mathrm{Mn}$ contributes significantly to

the contamination of the water in the area. The PI values however, indicates that locations W7,

Table 4:Results of Contamination Index of the heavy metals in the area

\begin{tabular}{|l|l|l|}
\hline $\begin{array}{l}\text { Location ID/ water } \\
\text { type }\end{array}$ & $\begin{array}{l}\text { Contamination } \\
\text { index }\end{array}$ & Remark \\
\hline W1/Pond quarry & 0.150 & $\begin{array}{l}\text { Not } \\
\text { contaminated }\end{array}$ \\
\hline W8/Pond quarry & 0.070 & $\begin{array}{l}\text { Not } \\
\text { contaminated }\end{array}$ \\
\hline W10/ Pond barite & $\mathbf{2 6 6 . 7 5 0}$ & Contaminated \\
\hline W2/ Stream quarry & 0.100 & $\begin{array}{l}\text { Not } \\
\text { contaminated }\end{array}$ \\
\hline W4/ Stream quarry & 0.160 & $\begin{array}{l}\text { Not } \\
\text { contaminated }\end{array}$ \\
\hline W6/ Stream quarry & 0.380 & $\begin{array}{l}\text { Not } \\
\text { contaminated }\end{array}$ \\
\hline W9/ river quarry & 0.070 & $\begin{array}{l}\text { Not } \\
\text { contaminated }\end{array}$ \\
\hline W11/ Stream barite & 182.570 & Contaminated \\
\hline W3/ Borehole quarry & 0.140 & $\begin{array}{l}\text { Not } \\
\text { contaminated }\end{array}$ \\
\hline W5/ Borehole quarry & 0.200 & $\begin{array}{l}\text { Not } \\
\text { contaminated }\end{array}$ \\
\hline W7/ Borehole quarry & 5.000 & Contaminated \\
\hline $\begin{array}{l}\text { W12/ Borehole } \\
\text { barite }\end{array}$ & 180.320 & Contaminated \\
\hline
\end{tabular}

W10, W11 and W12 are severely contaminated while W1, W2, W3, W4, W5, W6, W8 and W9 are not contaminated. Again, the water sources around the barite mine areas showed high level of contamination compared to those around the quarry areas. This is an indication that barite mining has impacted the area more compared to quarrying.

Table 5:Results of single factor pollution index of metals and Nemerow pollution index of the water

\begin{tabular}{|c|c|c|c|c|c|c|c|c|c|c|c|}
\hline $\begin{array}{l}\text { Loc. ID/ water } \\
\text { type }\end{array}$ & $\mathrm{Ba}$ & $\mathrm{Cr}$ & $\mathrm{Cu}$ & $\mathrm{Fe}$ & Mn & $\mathbf{P b}$ & $\mathrm{Zn}$ & $F_{\text {ave }}$ & $F_{\max }$ & $\mathbf{P I}$ & Remark \\
\hline $\begin{array}{l}\text { W1/ pond } \\
\text { quarry }\end{array}$ & 0.030 & 0.060 & 0.000 & 0.060 & 0.000 & 0.000 & 0.000 & 0.021 & 0.060 & 0.045 & $\begin{array}{l}\text { Not } \\
\text { contaminated }\end{array}$ \\
\hline $\begin{array}{l}\text { W8/ pond } \\
\text { quarry }\end{array}$ & 0.030 & 0.000 & 0.000 & 0.040 & 0.000 & 0.000 & 0.000 & 0.010 & 0.043 & 0.031 & $\begin{array}{l}\text { Not } \\
\text { contaminated }\end{array}$ \\
\hline $\begin{array}{l}\text { W10/ pond } \\
\text { barite }\end{array}$ & 19.710 & 0.200 & 103.000 & 13.670 & 14.370 & 110.400 & 5.400 & 38.117 & 110.400 & 82.587 & $\begin{array}{l}\text { Severely } \\
\text { contaminated }\end{array}$ \\
\hline $\begin{array}{ll}\text { W2/ } & \text { stream } \\
\text { quarry } & \end{array}$ & 0.010 & 0.000 & 0.000 & 0.000 & 0.050 & 0.000 & 0.040 & 0.014 & 0.046 & 0.034 & $\begin{array}{l}\text { Not } \\
\text { contaminated }\end{array}$ \\
\hline $\begin{array}{ll}\text { W4/ } & \text { stream } \\
\text { quarry } & \\
\end{array}$ & 0.030 & 0.000 & 0.020 & 0.070 & 0.000 & 0.000 & 0.040 & 0.023 & 0.070 & 0.052 & $\begin{array}{l}\text { Not } \\
\text { contaminated }\end{array}$ \\
\hline $\begin{array}{ll}\text { W6/ stream } \\
\text { quarry }\end{array}$ & 0.030 & 0.020 & 0.020 & 0.130 & 0.000 & 0.000 & 0.180 & 0.054 & 0.180 & 0.133 & $\begin{array}{l}\text { Not } \\
\text { contaminated }\end{array}$ \\
\hline $\begin{array}{ll}\text { W9/ } & \text { river } \\
\text { quarry } & \end{array}$ & 0.030 & 0.020 & 0.020 & 0.000 & 0.000 & 0.000 & 0.000 & 0.010 & 0.029 & 0.022 & $\begin{array}{l}\text { Not } \\
\text { contaminated }\end{array}$ \\
\hline $\begin{array}{l}\text { W11/ stream } \\
\text { barite }\end{array}$ & 8.000 & 0.200 & 35.200 & 6.000 & 15.970 & 113.000 & 4.200 & 26.081 & 113.000 & 82.004 & $\begin{array}{l}\text { Severely } \\
\text { contaminated }\end{array}$ \\
\hline $\begin{array}{l}\text { W3/ borehole } \\
\text { quarry }\end{array}$ & 0.040 & 0.000 & 0.000 & 0.000 & 0.040 & 0.000 & 0.060 & 0.020 & 0.060 & 0.045 & $\begin{array}{l}\text { Not } \\
\text { contaminated }\end{array}$ \\
\hline $\begin{array}{l}\text { W7I borehole } \\
\text { quarry }\end{array}$ & 0.290 & 0.040 & 0.000 & 0.000 & 0.070 & 0.000 & 4.600 & 0.714 & 4.600 & 3.292 & $\begin{array}{l}\text { Severely } \\
\text { contaminated }\end{array}$ \\
\hline $\begin{array}{l}\text { W5/ borehole } \\
\text { quarry }\end{array}$ & 0.100 & 0.080 & 0.020 & 0.000 & 0.000 & 0.000 & 0.000 & 0.029 & 0.100 & 0.074 & $\begin{array}{l}\text { Not } \\
\text { contaminated }\end{array}$ \\
\hline $\begin{array}{l}\text { W12/borehole } \\
\text { barite }\end{array}$ & 5.890 & 0.600 & 47.000 & 2.670 & 13.970 & 105.600 & 4.600 & 25.760 & 105.600 & 76.860 & $\begin{array}{l}\text { Severely } \\
\text { contaminated }\end{array}$ \\
\hline Min & 0.010 & 0.000 & 0.000 & 0.000 & 15.970 & 0.000 & 0.000 & 0.010 & 0.029 & 0.022 & - \\
\hline Max & 19.710 & 0.600 & 103.000 & 13.670 & 0.000 & 113.000 & 5.400 & 38.117 & 113.000 & 82.587 & - \\
\hline Mean & 2.850 & 0.100 & 15.440 & 1.890 & 3.700 & 27.420 & 1.590 & 8.257 & 27.849 & 20.436 & - \\
\hline
\end{tabular}




\section{CONCLUSION}

The investigation reveals that, the mean concentration of $\mathrm{Ba}, \mathrm{Cu}, \mathrm{Mn}, \mathrm{Pb}$ and $\mathrm{Zn}$ in the watersources within the study area were above the recommended standard for drinking water quality, hence it is not suitable for human consumption. The results of the contamination Index showed that $33 \%$ of the samples were contaminated. The average single factor pollution index, $\mathrm{F}$ indicated that the waters are not contaminated with $\mathrm{Cr}$, but slightly contaminated with $\mathrm{Fe}$ and $\mathrm{Zn}$, moderately contaminated with $\mathrm{Ba}$ and severely contaminated with $\mathrm{Cu}, \mathrm{Mn}$ and $\mathrm{Pb}$. Furthermore, the Nemerow comprehensive pollution index, PI suggest that $67 \%$ of the water samples analyzed are not contaminated, while the remaining samples were severely contaminated. Generally, the areas around the barite mines showed elevated levels of heavy metal concentration compared to locations around the quarries, and the source of these metals may be attributed to the activities of barite mining in the area. It is recommended that water from surface and groundwater sources should be treated before drinking, to forestall health challenges associated with the consumption of water contaminated with these heavy metals.

\section{REFERENCES}

Adamu, C. I., 2000. Environmental Geochemical Studies of ArufuPb-Zn-Ag Min-ingDistricts, Northeastern Nigeria. University of Calabar, Nigeria (M.Sc. thesis).

Adamu, C. I., 2011. Geoenvironmental Studies of Barite Mines in Parts of Oban Massifand Mamfe Embayment, Southeastern Nigeria. University of Calabar, Nigeria(Ph.D. dissertation).

Adamu, C. I., Nganje, T. and Edet, A., 2013. Hydrochemical Assessment of pond and stream Water near abandoned barite mine sites in parts of Oban Massif and Mamfe Embayment, Southeastern Nigeria. Environ Earth Sci. DOI 10.1007/s12665-013-2757-5.

Adamu, C. I., Nganje, T. N. and Edet, A., 2014. Heavy metal contamination and health risk assessment associated with abandoned barite mines in Cross River State, southeastern Nigeria. Environmental Nanotechnology Monitoring and Management. http://dx.doi.org/10.10 16/j.enmm. 2014.11.001

Adamu, C. I., Nganje, T. N. and Edet, A., 2015. Major and Trace Element pollution of Sediments associated with abandoned barite mines in parts of Oban Massif and Mamfe Embayment, Southeastern Nigeria. Journal of Geochemical Exploration. 151:1-33.

CRBDA 2008. Hydrogeological survey of lower Cross River Basin: Final Report. Cross River Basin Development Authority, Calabar, Nigeria. 158p.
Egeh, E.U., Ekwueme, B. N. and Akpeke, B., 2004. The appraisal of a proposed barite quarryin Akpet area, Cross River State, from resistivity investigation. Global Journal of Geological Science. 2 (2):171-175.

Ekwueme, B. N., 1995. Geochemistry of crystalline basement rocks in S. W. Ugep, Nigeria. Global Journal of Geological Sciences 1: 143-157.

Ekwueme, B. N. and Onyeagocha, A. C., 1986. Geochemistry of meta-sedimentary rocks of Uwet area, Oban massif, Southeastern Nigeria. Geol. Rundsch. 75 (2): 411-420.

FOS. 2003. Report of National Modular Child Labour Survey-Nigeria 2000/2001, Abuja; Federal Government of Nigeria.

Iloeje, N. P., 1991. A new geography of Nigeria. Lagos: Longman.

NBS. 2013. Main Report of Multiple Indicator Cluster Survey-Nigeria 2011, Abuja; Federal Republic of Nigeria.

NBS. 2014. Summary Findings of National Nutrition and Health Survey, $9^{\text {th }}$ February to $5^{\text {th }}$ May 2014 Nigeria.Abuja; Federal Government of Nigeria.

Ochelebe, I., Ekwere, A. S. and Ekwere, S. J., 2017. Environmental Implication of the Distribution of Heavy Metals in Soils and Water in Okpoma Area, Southeastern Nigeria. International Journal of Science and Engineering Investigations. 6(69):105-113.

Oden, M. I., 2012. Barite veins in the Benue Trough: field characteristics, the qualityissue and some tectonic implications. Environ. Nat. Res. 2 (2): 21-32.

SON., 2015. Nigerian Standard for DrinkingWater Quality. Abuja, StandardOrganization of Nigeria.

WHO., 2008. Guideline for Drinking-water Quality (3rd ed. Incorporating 1 st and $\left.2^{\text {nd }} A g e n d a\right)$, Vol. 1. Recommendations. Geneva., pp. 668p.

Yang, C.L., Guo, R.P., Yue, Q.L., Zhou, K., Wu, Z.F. 2013. Environmental quality assessment and spatial pattern of potentially toxic elements in soils of GuangdongProvince, China. Environ. Earth Sci. 70: 1903-1910.

Zhang, Q., Feng, M. and Hoa, X., 2018. Application of Nemerow Index Method and Integrated Water Quality Index Method in Water Quality Assessment of Zhangze Reservoir. IOP Conf series. Earth and Environmental Science. 128 012160 . 